\title{
Extension-block pinning to treat bony mallet finger: Is a transfixation pin necessary?
}

\author{
๑ Sercan Çapkın, M.D., ${ }^{1} \odot$ Abdul Fettah Büyük, M.D., ${ }^{2} \odot$ Serkan Sürücü, M.D., ${ }^{3}$ \\ 들 Özgür Mert Bakan, ${ }^{4}$ M.D., 다 Doğan Atlıhan, M.D. ${ }^{3}$
}

\begin{abstract}
${ }^{1}$ Department of Orthopaedics and Traumatology, Division of Hand Surgery, Uludağ University Faculty of Medicine, Bursa-Turkey 2Department of Orthopaedics and Traumatology, Baltalimanı Bone Diseases Training and Research Hospital, İstanbul-Turkey ${ }^{3}$ Department of Orthopaedics and Traumatology, Haseki Training and Research Hospital, İstanbul-Turkey

${ }^{4}$ Department of Orthopaedics and Traumatology, Ege University Faculty of Medicine, İzmir-Turkey
\end{abstract}

\begin{abstract}
BACKGROUND: Extension-block pinning is a popular treatment for mallet fractures, but it is associated with several pitfalls. Of note, transfixation Kirschner wires used to fix the distal interphalangeal (DIP) joint may cause iatrogenic nail bed injury, bone fragment rotation, chondral damage, or osteoarthritis. The objective of this study was to determine whether a transfixation pin was necessary for extension-block pinning in the treatment of bony mallet fracture.

METHODS: Patients were treated with a pin-orthosis extension-block technique if they had been diagnosed with a type IVB mallet fracture according to Doyle's classification. Radiological outcomes were evaluated based on postoperative X-ray results, and functional outcomes were evaluated using Crawford's criteria.

RESULTS: Thirteen patients ( 9 males and 4 females) with a mean age of 26 years were included. The mean time between the injury and surgery was 3.3 days, and the mean follow-up period was 8.2 months (range: 4-12 months). Radiographic bone union was achieved in all patients within an average of 5.1 weeks (range: 5-6 weeks). At the final follow-up, the DIP joint had an average degree of flexion of $76.1^{\circ}$ (range: $65^{\circ}-80^{\circ}$ ) and an average extension deficit of $3.84^{\circ}$ (range: $0^{\circ}-15^{\circ}$ ). According to Crawford's criteria, 8 patients had excellent results, 4 patients had good results, and I patient had a fair result. No patient reported pain at the final follow-up.
\end{abstract}

CONCLUSION: Satisfactory clinical and radiological outcomes were obtained with the pin-orthosis extension-block technique. Future prospective and randomized studies are justified to confirm the efficacy of this technique.

Keywords: Bony mallet finger; extension-block pinning; pin-orthosis; transfixation pin.

\section{INTRODUCTION}

A mallet fracture involves damage to the terminal extensor mechanism caused by bony avulsion of the distal phalanx base. Such fractures typically result from forced flexion of the extended distal interphalangeal (DIP) joint. ${ }^{\left[{ }^{[]}\right.}$Although several treatment options have been reported, from conservative to surgical management, the optimal treatment continues to be a subject of debate. ${ }^{[2-5]}$ However, surgery is usually advocated when the dorsal fragment involves more than one-third of the articular surface or when there is volar subluxation. ${ }^{[6-8]}$ The main surgical options are Kirschner $(\mathrm{K})$-wire fixation, ${ }^{[9]}$ tension band wiring, ${ }^{[7]}$ micro screws, ${ }^{[10]}$ pull-out wire fixation, ${ }^{[1]}$ hook plate, ${ }^{[12]}$ small external fixator, ${ }^{[2]}$ or extension-block fixation. ${ }^{[8,13-16]}$ The extension-block pinning technique reported by Ishiguro et al. $^{[13]}$ is among the most popular treatment methods for mallet fractures, but is associated with several potential problems. Transfixation K-wires used to fix the DIP joint may cause iatrogenic nail bed injury, bone fragment rotation, chondral damage, or osteoarthritis. Furthermore, the

Cite this article as: Çapkın S, Büyük AF, Sürücü B, Bakan ÖM, Atlıhan D. Extension-block pinning to treat bony mallet finger: Is a transfixation pin necessary?. Ulus Travma Acil Cerrahi Derg 2019;25:281-286.

Address for correspondence: Sercan Çapkın, M.D.

Uludağ Üniversitesi Tıp Fakültesi, Ortopedi ve Travmatoloji Anabilim Dalı, El Cerrahisi Bilim Dalı, Bursa 16059, Turkey.

Tel: +90 224 - 2950000 E-mail: sercancapkn@gmail.com

Ulus Travma Acil Cerrahi Derg 2019;25(3):28I-286 DOI: 10.5505/tjtes.2018.5995I Submitted: 22.05.2018 Accepted: 30.10.2018 Online: 02.1I.2018

Copyright 2019 Turkish Association of Trauma and Emergency Surgery 
Table I. Doyle classification

\section{Type characteristics}

I Closed injury \pm avulsion fracture

II Open injury (laceration at or around distal interphalangeal joint)

III Open injury+deep soft tissue abrasion involving loss of skin and extendor tendon substance

IV A: Growth plate fracture (pediatric)

B: Fracture fragment involving $20 \%-50 \%$ of articular surface (adult)

C: Fracture fragment involving $>50 \%$ of articular surface (adult)

need for prolonged immobilization may cause flexion contracture of the DIP joint. Presently described is a simple and minimally invasive pin-orthosis extension-block technique for the management of mallet fractures.
Approval for this prospective study was granted by Haseki Training and Research Hospital Ethics Committee (date: 3 I.05.2017, approval no: 497), and all of the participating patients provided written, informed consent before enrollment. The only inclusion criterion was for the patient to have a Doyle type IVB mallet fracture (Table I). ${ }^{[1]}$

\section{MATERIALS AND METHODS}

\section{Surgical Technique}

All of the procedures were performed by a single surgeon, using an image intensifier under digital block anesthesia without a tourniquet. Under lateral-view fluoroscopy, the DIP joint was then held in maximum flexion, and a I.2-mm K-wire was inserted just behind the fragment into the dorsal rim of the articular surface of the middle phalangeal head. Insertion was at an angle of approximately $40^{\circ}$ to $45^{\circ}$ relative to the longitudinal axis. The fracture was then reduced with the DIP
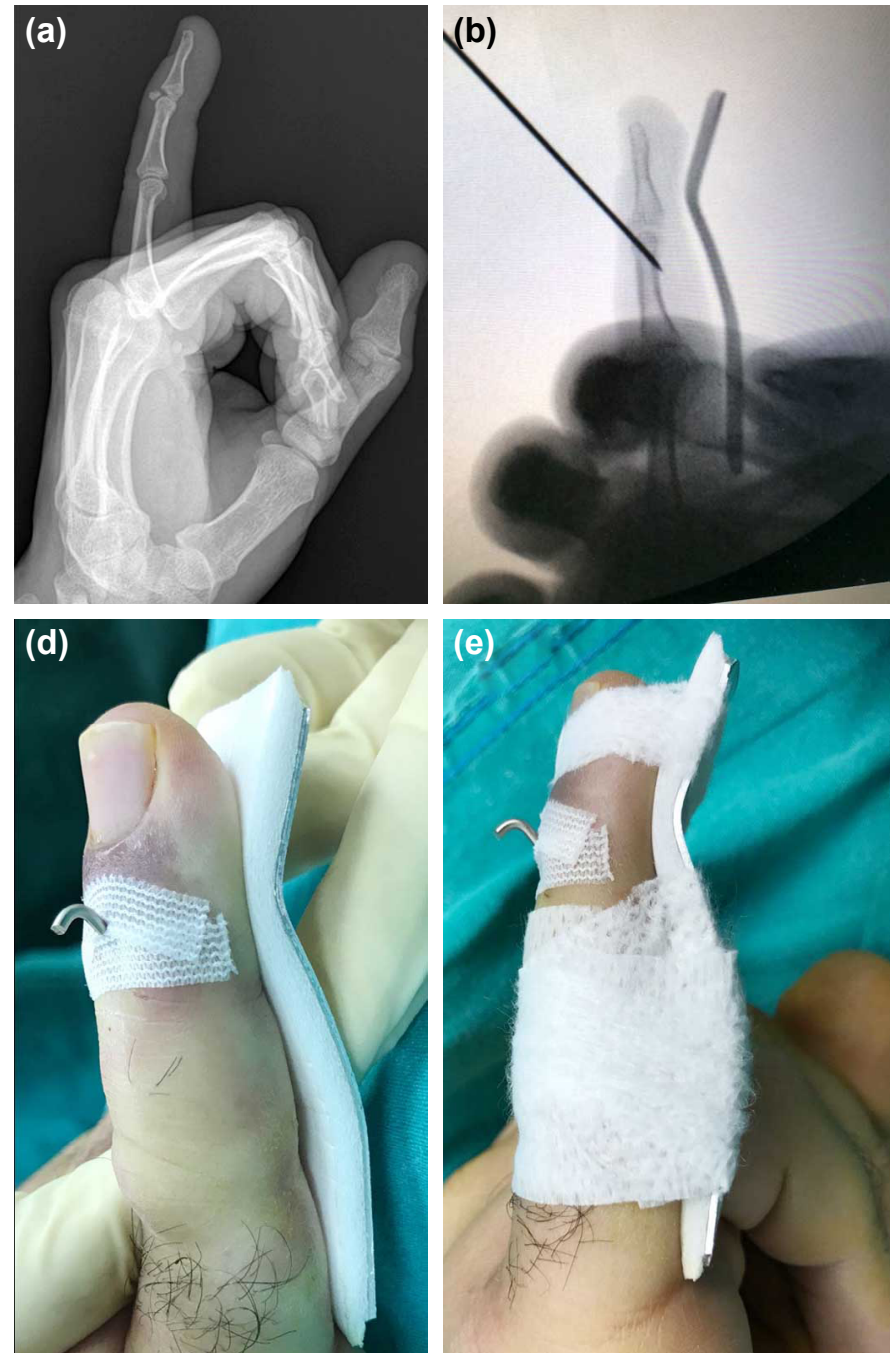
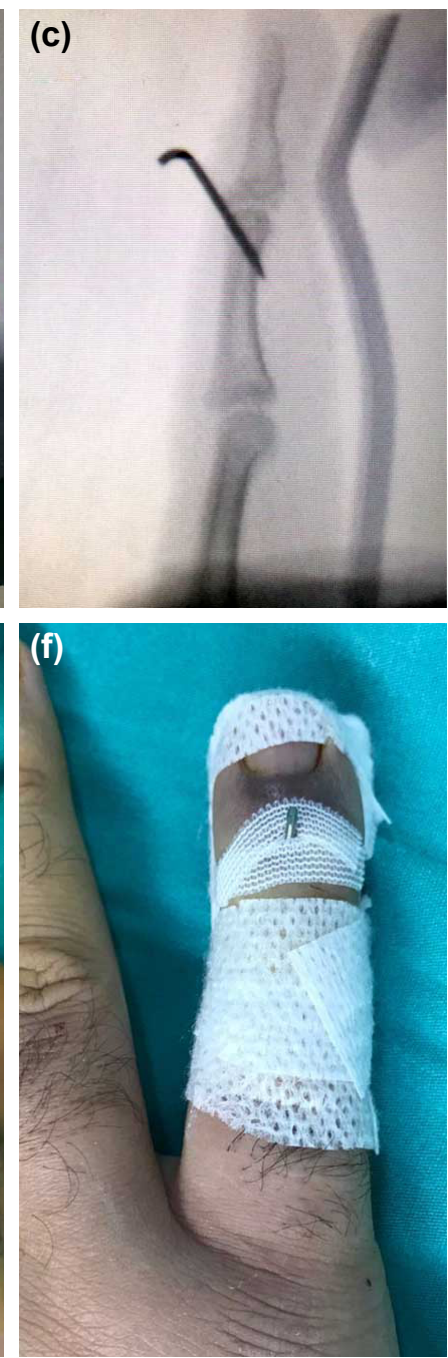

Figure 1. A 28-year-old male with a mallet fracture of the right little finger. (a) Preoperative lateral X-ray of a type IVB mallet fracture. (b) A 1.2-mm Kirschner wire was inserted just behind the fragment into the dorsal rim of the articular surface of the middle phalangeal head, at an angle of approximately $40^{\circ}-45^{\circ}$ relative to its longitudinal axis, and an aluminum orthotic device was applied. (c) Postoperative lateral view with fluoroscopy. (d-f) Clinical appearance after applying the aluminum orthotic device. 
joint in traction and slight extension, and the K-wire was cut to between 0.5 and $\mathrm{I} \mathrm{cm}$ above the skin. Wound dressing was accomplished with sterile strips (Steri-Strip; The $3 \mathrm{M} \mathrm{Co.,}$ Maplewood, MN, USA). After appropriate reduction was achieved, an aluminum splint was applied to the volar side, keeping the finger in the reduced position and allowing the metacarpophalangeal joint to have free movement. The operation was terminated after obtaining a satisfactory lateral fluoroscopy image in the splinted position (Fig. Ia-f).

\section{Postoperative Management}

The patients were discharged on the day of surgery and requested to return for weekly review by the surgeon who performed the surgery. Dressing was managed by holding the DIP joint in extension so as not to disrupt the fracture reduction. After 4 weeks, the $\mathrm{K}$-wire was removed, and the orthosis was left in place for another week. If union was not complete at this time, the orthosis was retained until the end of the sixth week. Lateral and posteroanterior plain radiographs were taken immediately after fixation and weekly (Fig. 2 ). Active range of motion exercises were initiated immediately after removal of the aluminum orthosis.

\section{Evaluation}

Clinical and radiographic evaluations were conducted in all cases. Fracture union was defined as the X-ray presence of bridging trabeculae and a radiolucent line at the fracture gap and the clinical absence of tenderness at the fracture site. Complications and progress with bony union were evaluated with clinical examinations and weekly radiographs. The active range of motion and extension lag of the DIP joint was measured with a goniometer. Full flexion was considered to be achieved when the angle of the injured side reached that of the opposite side at follow-up. Functional outcomes were evaluated using Crawford's criteria (Table 2). ${ }^{[17]}$

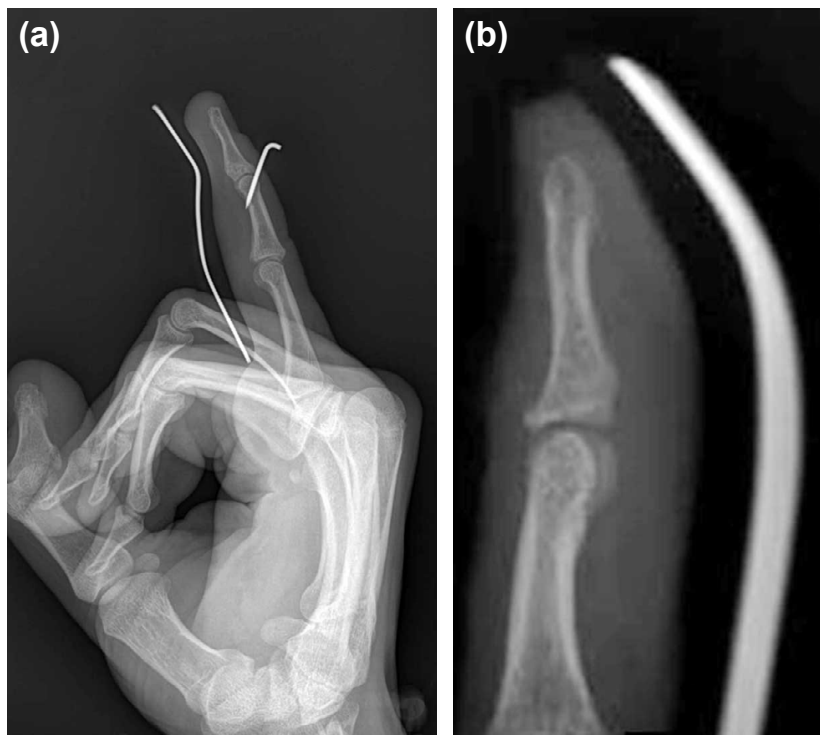

Figure 2. (a) Early postoperative lateral X-ray view. (b) Lateral X-ray view after week 6 , before the aluminum orthotic splint was removed.
Table 2. Crawford criteria for the assessment of mallet finger outcome

\begin{tabular}{lc}
\hline Grade & Characteristics of DIP joint \\
\hline Excellent & Full extension \\
& Full flexion \\
& No pain \\
Good & Extension deficit $0^{\circ}-10^{\circ}$ \\
& Full flexion \\
Fair & No pain \\
& Extension deficit $10^{\circ}-25^{\circ}$ \\
& Any flexion loss \\
Poor & No pain \\
& Extension deficit $>25^{\circ}$ \\
& Persistent pain \\
\hline
\end{tabular}

DIP: Distal interphalangeal.

\section{RESULTS}

Thirteen patients ( 9 males and 4 females) with a mean age of 26 years (range: 17-36 years) were treated with the current technique (Table 3). Eight fractures were of the right hand and 5 were of the left hand, with the ring finger being most commonly affected ( 6 cases), followed by the little finger ( 4 cases), middle finger ( 2 cases) and index finger ( I case). The causes of injury were a fall ( 7 cases), sports injury ( 3 cases), work accident ( 2 cases) and a fight ( 1 case). The mean time between the injury and surgery was 3.3 days.

The mean follow-up period was 8.2 months (range: 4-12 months), with all K-wires removed after 4 weeks. However, union was incomplete after 5 weeks in 2 patients, so the orthoses were retained until the end of week 6 in these cases, meaning that overall the orthotic splints were used for an a mean of 5.1 weeks. Radiographic bone union was achieved by either week 5 or 6 (mean of 5.1). At the final follow-up, the DIP had an average flexion of $76.1^{\circ}$ (range: $65^{\circ}-80^{\circ}$ ) and an average extension deficit of $3.84^{\circ}$ (range: $0^{\circ}-15^{\circ}$ ).

According to Crawford's criteria, 8 patients had excellent results, 4 patients had good results, and I patient had a fair result. No patient reported pain at the final follow-up. There were no complications, such a comminution of the fracture fragment, nail deformity, volar subluxation, or dislocation or DIP joint osteoarthritis. Two cases developed superficial infection, and I case developed skin necrosis; all were treated with oral antibiotics and wound care, as needed.

\section{DISCUSSION}

There is no optimal treatment for mallet finger injuries; there are a range of potential treatments that are considered appropriate. ${ }^{[14]}$ Ishiguro et al. ${ }^{[13]}$ first described extension-block pin- 
Table 3. Summary of patient data

\begin{tabular}{|c|c|c|c|c|c|c|}
\hline $\begin{array}{l}\text { Patient } \\
\text { no }\end{array}$ & $\begin{array}{c}\begin{array}{c}\text { Age } \\
\text { (years) }\end{array}\end{array}$ & Sex & Affected finger & Cause & $\begin{array}{l}\text { Time from injury } \\
\text { to surgery (days) }\end{array}$ & $\begin{array}{l}\text { Follow-up period } \\
\text { (months) }\end{array}$ \\
\hline I & 20 & Male & Left-little & Fall & 2 & 12 \\
\hline 2 & 33 & Male & Right-index & Fall & 2 & 10 \\
\hline 3 & 28 & Male & Right-little & Fall & 5 & 11 \\
\hline 4 & 24 & Male & Right-little & Sport injury & 2 & 9 \\
\hline 5 & 19 & Female & Left-little & Sport injury & 2 & 12 \\
\hline 6 & 23 & Male & Left-middle & Fall & 10 & 10 \\
\hline 7 & 31 & Female & Right-ring & Work accident & 3 & 9 \\
\hline 8 & 29 & Male & Right-ring & Fall & 2 & 8 \\
\hline 9 & 17 & Male & Left-ring & Fight & 3 & 6 \\
\hline 10 & 20 & Female & Right-middle & Sport injury & 4 & 7 \\
\hline II & 27 & Female & Right-ring & Fall & 1 & 5 \\
\hline 12 & 31 & Male & Right-ring & Fall & 2 & 4 \\
\hline 13 & 36 & Male & Left-ring & Work accident & 5 & 4 \\
\hline
\end{tabular}

ning as a simple and reliable method, and it has since become one of the most popular methods of treating mallet finger, with later modifications. ${ }^{[15-21]}$ Most of these resulting techniques involve some use of $\mathrm{K}$-wire fixation across the DIP joint, despite awareness that it is difficult to insert a temporary transfixation pin through the DIP joint. Potential disadvantages associated with repeated attempts at insertion include articular cartilage damage that can lead to secondary osteoarthritis, especially if more than one attempt at pin insertion is needed, ${ }^{[8]}$ and iatrogenic nail bed injury. However, the presently described method did not require that a transfixation pin be inserted through the joint, which should reasonably be expected to decrease the risk of secondary arthritis. Indeed, we observed no arthritic change or nail deformity in any case during the 8.2-month mean follow-up period. Early union has previously been reported in 5 to 7 weeks with extension-block fixation, ${ }^{[13,15,16]}$ and the results of this study compared favorably.

Miura $^{[2]}$ described a modified version of the extension-block fixation method that was designed to achieve accurate reduction and stable fixation by controlling dorsal rotation of the fragment with an external fixator. Twelve acute mallet fractures were treated with this method and not only were all united after an average of $5 \pm I$ weeks, but there were no arthritic changes after an average follow-up of 4 months. However, that design required a bulky fixator and a DIP joint splint for an average of 6 weeks. It also required increased surgical time, increased radiation exposure, and a second surgical procedure to remove the fixator. We achieved comparable results with a less invasive method, albeit with the disadvantage that treatment success was closely related to patient compliance.

Miranda et al. ${ }^{[22]}$ described a simple technique to improve intraoperative bony mallet reduction and avoid complications, such as articular cartilage damage, nail bed damage, and dorsal skin necrosis. They used a blunt needle as a joystick to reduce the bony fragment of a stab incision. After reduction was achieved, a dorsal splint was applied holding the DIP joint in $15^{\circ}$ to $30^{\circ}$ extension. They achieved and maintained satisfactory reduction, and reported their technique as a less-invasive management option for bony mallet injures. Criticism of this technique focused on the difficulty of maintaining the reduction of the unstable fragment with the dorsal splint alone due to the extensor tendon pulling on the bony fragment. [23] In the present study, only an extension-block K-wire was used to reduce and maintain reduction. Once the appropriate reduction was achieved, an aluminum splint was applied to the volar side instead of using transfixation wire.

Karslıoglu et al. ${ }^{[24]}$ emphasized that rotation of the mallet fragment can prevent appropriate fracture reduction and may result in extension lag, incongruity of the articular surface, premature osteoarthritis, or stiffness. They described a percutaneous derotation technique utilizing needle-tip reduction during surgery for type IIb and IIlc patients according to the Wehbe and Schneider classification. ${ }^{[25]}$ They found that derotation of type II ( $25 \%$ rotation) and III ( $50 \%$ rotation) mallet pieces with closed reduction was simple, effective, and could prevent surgical failure. ${ }^{[24]}$ The transfixation K-wire was used as in the original extension-block technique. The technique presented in the current study was not used in the presence of rotational deformity. Patients who have rotational deformity may benefit from direct reduction techniques and more rigid fixation.

Closed reduction by extension-block K-wire fixation is a relative contraindication in bony mallet fractures older than 5 weeks. Reduction may not be achieved due to scar tissue that 
prevents closed reduction in these fractures. ${ }^{[13]}$ Open reduction to restore the congruity of the articular surface is usually indicated in such cases. ${ }^{[14]}$ Pegoli et al. ${ }^{[8]}$ used percutaneous curettage with an Ishiguro extension-block K-wire to treat mallet fracture cases older than 5 weeks. All of the patients in this study were treated in the early period, with the latest presentation at 10 days after trauma.

Our indications for the pin-orthosis extension-block technique include acute bony mallet injuries in compliant patients who are well-motivated for splint use. Because the fracture fragment is indirectly reduced, anatomical reduction may not be achieved if rotation of the fracture fragment is present. Fractures that involve more than $50 \%$ of the articular surface may be difficult to reduce with the presently described technique, and even if reduction is achieved, this reduction may not be protected without rigid fixation. Therefore, patients with Doyle type IVC mallet fractures and fractures with irreducible subluxation of the distal phalanx formed the exclusion criteria for this study. Patients with open injuries were also excluded.

This study has several limitations. Of note, we only included a small sample that was limited to patients with Doyle type IVB mallet fractures. Further research will be essential to assess the efficacy of this approach with fracture fragments that involve more than $50 \%$ of the articular surface (e.g., Doyle type IVC). Finally, the follow-up period may have been too short to observe long-term adverse outcomes.

\section{Conclusion}

In conclusion, our modified technique reduces the risks of iatrogenic chondral injury, joint degeneration, and nail bed injury, as well as fracture displacement due to interposition of the K-wire used for transfixation. Clinically, it also reduces the duration of surgery and radiation exposure. The pin-orthosis extension-block technique may, therefore, be a useful alternative method for the treatment of mallet fractures, benefitting from being less invasive and easy to apply, and without damaging key anatomical structures.

\section{Conflict of interest: None declared.}

\section{REFERENCES}

1. Doyle J. Extensor tendons: acute injuries. In: Green DP, Hotchkiss RN, Pederson WC, editors. Operative hand surgery. 4th ed. Churchill Livingstone: Philadelphia; 1999. p. 1950-70.

2. Miura T. Extension block pinning using a small external fixator for mallet finger fractures. J Hand Surg Am 2013;38:2348-52.

3. Wada T, Oda T. Mallet fingers with bone avulsion and DIP joint subluxation. J Hand Surg Eur Vol 2015;40:8-15.

4. Kim JK, Kim DJ. The risk factors associated with subluxation of the distal interphalangeal joint in mallet fracture. J Hand Surg Eur Vol
2015;40:63-7.

5. Yoon JO, Baek H, Kim JK. The Outcomes of Extension Block Pinning and Nonsurgical Management for Mallet Fracture. J Hand Surg Am 2017;42:387.e1-387.e7.

6. Hamas RS, Horrell ED, Pierret GP. Treatment of mallet finger due to intra-articular fracture of the distal phalanx. J Hand Surg Am 1978;3:3613.

7. Damron TA, Engber WD. Surgical treatment of mallet finger fractures by tension band technique. Clin Orthop Relat Res 1994;133-40.

8. Pegoli L, Toh S, Arai K, Fukuda A, Nishikawa S, Vallejo IG. The Ishiguro extension block technique for the treatment of mallet finger fracture: indications and clinical results. J Hand Surg Br 2003;28:15-7.

9. Lubahn JD. Mallet finger fractures: a comparison of open and closed technique. J Hand Surg Am 1989;14:394-6.

10. Kronlage SC, Faust D. Open reduction and screw fixation of mallet fractures. J Hand Surg Br 2004;29:135-8.

11. Zhang X, Meng H, Shao X, Wen S, Zhu H, Mi X. Pull-out wire fixation for acute mallet finger fractures with $\mathrm{k}$-wire stabilization of the distal interphalangeal joint. J Hand Surg Am 2010;35:1864-9.

12. Teoh LC, Lee JY. Mallet fractures: a novel approach to internal fixation using a hook plate. J Hand Surg Eur Vol 2007;32:24-30.

13. Ishiguro T, Itoh Y, Yabe Y, Hashizume N. Extension block with Kirschner wire for fracture dislocation of the distal interphalangeal joint. Tech Hand Up Extrem Surg 1997;1:95-102.

14. Lin JS, Samora JB. Surgical and Nonsurgical Management of Mallet Finger: A SystematicReview. J Hand Surg Am 2018;43:146-163.e2.

15. Hofmeister EP, Mazurek MT, Shin AY, Bishop AT. Extension block pinning for large mallet fractures. J Hand Surg Am 2003;28:453-9.

16. Lee YH, Kim JY, Chung MS, Baek GH, Gong HS, Lee SK. Two extension block Kirschner wire technique for mallet finger fractures. J Bone Joint Surg Br 2009;91:1478-81.

17. Inoue G. Closed reduction of mallet fractures using extension-block Kirschner wire. J Orthop Trauma 1992;6:413-5.

18. Crawford GP. The molded polythene splint for mallet finger deformities. J Hand Surg Am 1984;9:231-7.

19. Yoon HK, Kim BM, Rah SK. Modified extension block technique for large mallet fracture. J Korean Soc Surg Hand 2005;10:227-33.

20. Lee SK, Kim KJ, Yang DS, Moon KH, Choy WS. Modified extensionblock K-wire fixation technique for the treatment of bony mallet finger. Orthopedics 2010;33:728.

21. Chung DW, Lee JH. Anatomic reduction of mallet fractures using extension block and additional intrafocal pinning techniques. Clin Orthop Surg 2012;4:72-6.

22. Miranda BH, Murugesan L, Grobbelaar AO, Jemec B. PBNR: Percutaneous Blunt Needle Reduction of Bony Mallet Injuries. Tech Hand Up Extrem Surg 2015;19:81-3.

23. Karslioglu B, Tekin AC, Tasatan E. Percutaneous Blunt Needle Reduction (PBNR) Needs Stable Fixation. Tech Hand Up Extrem Surg 2018;22:35-6.

24. Karslığlu B, Uzun M, Tetik C, Tasatan E, Tekin AC, Buyukkurt CD. Derotation of the mallet piece: A crucial point in mallet fracture surgery. Hand Surg Rehabil 2018 Jun 6. doi: 10.1016/j.hansur.2018.03.004. [Epub ahead of print]

25. Wehbé MA, Schneider LH. Mallet fractures. J Bone Joint Surg Am 1984;66:658-69. 
ORİJINAL ÇALIŞMA - ÖZET

Kemiksel çekiç parmak tedavisi için ekstansiyon blok pinleme: Transfiksasyon pini gerekli mi? Dr. Sercan Çapkın, ${ }^{1}$ Dr. Abdul Fettah Büyük, ${ }^{2}$ Dr. Serkan Sürücü, ${ }^{3}$ Dr. Özgür Mert Bakan, ${ }^{4}$ Dr. Doğan Atıhan ${ }^{3}$

${ }^{1}$ Uludağ Üniversitesi Tıp Fakültesi, Ortopedi ve Travmatoloji Anabilim Dalı, El Cerrahisi Bilim Dalı, Bursa ${ }^{2}$ Baltalimanı Kemik Hastalıkları Eğitim ve Araştırma Hastanesi, Ortopedi ve Travmatoloji Kliniği, İstanbul

${ }^{3}$ Haseki Eğitim ve Araştırma Hastanesi, Ortopedi ve Travmatoloji Kliniği, İstanbul

${ }^{4}$ Ege Üniversitesi Tıp Fakültesi, Ortopedi ve Travmatoloji Kliniği, İzmir

AMAÇ: Kemiksel çekiç parmak yaralanmalarının tedavisinde popüler bir tedavi yöntemi olan ekstansiyon blok pinleme yönteminde kullanılan transfiksasyon pininin gerekliliğini araştırmak.

GEREÇ VE YÖNTEM: Doyle sınıflamasına göre tip 4B çekiç parmak yaralanması olan hastalar tariflediğimiz pin-ortez ekstansiyon blok yöntemi ile tedavi edildi. Radyolojik sonuçlar ameliyat sonrası çekilen röntgenlerle, fonksiyonel sonuçlar Crawford kriterlerine göre değerlendirildi.

BULGULAR: Yaş ortalaması 26 olan 13 hasta (9 erkek, 4 kadın) çalışmaya dahil edildi. Yaralanma ile cerrahi arasında geçen ortalama süre 3.3 gün, ortalama takip 8.2 ay (dağılım, 4-12 ay) dı. Tüm hastalarda ortalama 5.I haftada (dağılım, 5-6 hafta) radyolojik kemik kaynaması elde edildi. Son kontrollerde ortalam aktif distal interfalangeal eklem fleksiyonu $76.1^{\circ}$ (dağılım, $65^{\circ}-80^{\circ}$ ) ve ortalama ekstansiyon kaybı $3.84^{\circ}\left(\right.$ dağılım, $\left.0^{\circ}-15^{\circ}\right)$ di. Crawford kriterlerine göre, sekiz hastada mükemmel sonuç, dört hastada iyi sonuç, bir hastada kötü sonuç elde edildi. Son kontrollerde hiç bir hastada ağrı yoktu.

TARTIŞMA: Kullandığımız pin-ortez ekstansiyon blok tekniğinde tatmin edici klinik ve radyolojik sonuçlar elde ettik. Randomize kontrollü ve ileriye yönelik çalışmalar ile tekniğin etkinliği teyit edilecektir.

Anahtar sözcükler: Ekstansiyon-blok pinleme; kemik çekiç parmak; pin-ortez.

Ulus Travma Acil Cerrahi Derg 2019;25(3):28I-286 doi: 10.5505/tjtes.20।8.5995 I 